\title{
Impact of dental care on the oral health of in patients with trauma sequelae
}

\author{
Impacto do cuidado odontológico na saúde oral de pacientes com sequela de trauma \\ Impacto de la atención dental en la salud bucal de pacientes con traumatismo secuelas
}

Received: 06/06/2021 | Reviewed: 06/15/2021 | Accept: 06/22/2021 | Published: 07/05/2021

\author{
Maria Patrícia Rogério de Mendonça \\ ORCID: https://orcid.org/0000-0003-0142-457X \\ Instituto José Frota Hospital, Brazil \\ E-mail: patriciarogerio@live.com \\ Ana Karisse de Carvalho Andrade \\ ORCID: https://orcid.org/0000-0003-4704-939X \\ Instituto José Frota Hospital, Brazil \\ E-mail: anakarisse@hotmail.com \\ Manoel de Jesus Rodrigues Mello \\ ORCID: https://orcid.org/0000-0001-6032-577X \\ Centro Universitário Christus, Brazil \\ E-mail:mjrmello@gmail.com \\ Clarice Maia Soares de Alcântara Pinto \\ ORCID: https://orcid.org/0000-0002-0209-1482 \\ Instituto José Frota Hospital, Brazil \\ E-mail: dra.claricemaia@gmail.com \\ Paulo Goberlânio de Barros Silva \\ ORCID: https://orcid.org/0000-0002-1513-9027 \\ Universidade Federal do Ceará, Brazil \\ E-mail: paulo_goberlanio@yahoo.com.br \\ Abrahão Cavalcante Gomes de Souza Carvalho \\ ORCID: https://orcid.org/0000-0002-0581-2468 \\ Universidade Federal do Ceará, Brazil \\ E-mail: abrahao@ufc.br
}

\begin{abstract}
This study aims to assess oral health before and after dental care to adult patients restricted to bed with trauma sequelae, admitted to the Instituto Doutor José Frota (IJF) hospital, located in the city of Fortaleza, in the state of Ceará. This is a longitudinal study with adult patients with motor and cognitive disabilities, diagnosis of traumatic brain injury, spinal cord trauma, and exogenous intoxication. We evaluated 39 patients, using the World Health Organization (WHO) dental caries index and Bedside oral exam (BOE) before and after dental care. After two dental consultations, there was a reduction of $46 \%$ of decayed teeth, poor oral health decreased by $11 \%$ and $29.6 \%$ of the BOE index, and good oral health increased by $57 \%$. Although dental care in bed is challenging, it has proved effective, improving the health of the oral mucosa, perioral and dental surfaces and, consequently, reducing the likelihood of changes in oral health.
\end{abstract}

Keywords: Oral health; Oral hygiene; Cognitive dysfunction; Craniocerebral trauma.

\section{Resumo}

Este estudo tem como objetivo avaliar a saúde bucal antes e após o atendimento odontológico de pacientes adultos restritos ao leito com sequelas de trauma, internados no Hospital do Instituto Doutor José Frota (IJF), localizado na cidade de Fortaleza, no estado do Ceará. Este é um estudo longitudinal com pacientes adultos com deficiência motora e cognitiva, diagnóstico de traumatismo cranioencefálico, trauma raquimedular e intoxicação exógena. Foram avaliados 39 pacientes, utilizando o índice de cárie dentária da Organização Mundial da Saúde (OMS) e o exame bucal à beira do leito (BOE) antes e após o atendimento odontológico. Após duas consultas odontológicas, houve redução de $46 \%$ dos dentes cariados, a saúde bucal precária diminuiu $11 \%$ e $29,6 \%$ do índice BOE, e a saúde bucal boa aumentou $57 \%$. Embora o atendimento odontológico no leito seja um desafio, ele tem se mostrado eficaz, melhorando a saúde da mucosa bucal, dermatites periorais e das superfícies dentais e, consequentemente, reduzindo a probabilidade de alterações na saúde bucal.

Palavras-chave: Saúde bucal; Higiene bucal; Disfunção cognitiva; Traumatismos craniocerebrais.

\section{Resumen}

Este estudio tiene como objetivo evaluar la salud bucal antes y después de la atención odontológica a pacientes adultos restringidos a cama con secuelas traumáticas, ingresados en el hospital Instituto Doutor José Frota (IJF), ubicado en la ciudad de Fortaleza, en el estado de Ceará. Se trata de un estudio longitudinal con pacientes adultos con discapacidad motora y cognitiva, diagnóstico de traumatismo craneoencefálico, traumatismo medular e intoxicación exógena. 
Evaluamos a 39 pacientes, utilizando el índice de caries dental de la Organización Mundial de la Salud (OMS) y el Examen bucal de cabecera (BOE) antes y después de la atención dental. Después de dos consultas dentales, hubo una reducción del 46\% de los dientes cariados, la mala salud bucal disminuyó en un 11\% y el 29,6\% del índice BOE, y la buena salud bucal aumentó en un 57\%. Aunque el cuidado dental al lado de la cama es un desafío, se ha demostrado que es efectivo, mejorando la salud de la mucosa oral, la dermatitis perioral y las superficies dentales y, en consecuencia, reduciendo la probabilidad de cambios en la salud bucal. Aunque el cuidado dental en la cama es un desafío, ha demostrado ser efectivo, mejorando la salud de la mucosa bucal, las superficies perioral y dental y, en consecuencia, reduciendo la probabilidad de cambios en la salud bucal.

Palabras clave: Salud bucal; Higiene bucal; Disfunción cognitiva; Traumatismos craneocerebrales.

\section{Introduction}

Trauma is a lesion of varying length, intensity, and severity, which can be produced by different agents (physical, chemical, electrical), accidentally or intentionally, capable of producing local or systemic disorders, and may be irreversible. (Government of the state of Espírito Santo, 2018).

Trauma is public health problems and one of the main reasons for mortality and disability in developed countries that can cause social and economic consequences to individuals (Carvalho \&, 2015).

According to Carvalho, et al., (2015), the occurrence of trauma in the population has been growing due to a more active lifestyle, recklessness in traffic and the increase in violence. Urban violence is one of the factors that lead to the increase in physical trauma and one of the main causes of death among individuals aged up to 35 years (Carvalho, et al., 2015).

To exemplify a chemical and electrical trauma, burns may be due to trauma of thermal, electrical, chemical or radioactive origin, which can range from a small blister to more severe forms that are capable of triggering systemic responses proportional to the extension and the depth of these lesions (Wachtel, 1985).

Thus, according to the trauma care line in the emergency care network of the Unified Health System, trauma patients may be diagnosed with traumatic brain injury (TBI), spinal trauma (ST), and exogenous intoxication (Brazil, 2011; Brazil, 2013; Government of the State of Espírito Santos, 2018).

Infections associated with healthcare (HAI) (nosocomials) occur in patients admitted to hospital institutions, resulting in an increase in prolonged hospital stay, increased hospital costs, long-term disability, increased antimicrobial resistance and increased mortality rate (Khan, et al., 2017). Commonly present types of infections are: catheter-associated bloodstream infections, catheter-associated urinary tract infections, surgical site infections, and ventilator-associated pneumonia (PAV). O PAV is responsible for 9-27\% of infections in patients with assisted mechanical ventilation (Khan, et al., 2017).

The development of infection control programs with management representatives, workers and individuals admitted to hospitals is essential (Khan, et al., 2015; Khan, et al., 2017). It will be able to adopt infection tracking programs, adequate cleaning and disinfection of the environment, optimize the use of antibiotics, contact precautions and strict hand hygiene in order to prevent the spread of nosocomial infections (Fernando et al., 2017).

Hand hygiene is the simplest and most effective measure to prevent nosocomial infections that can be performed by health professionals (Brazil, 2009). The World Health Organization (WHO) recommends five moments for hand hygiene, namely: before contact with the patient, before performing aseptic procedures, after contact with the patient, after contact with bodily fluids and after contact with nearby areas of the patient, and can be performed with soap and water, for 8 to 20 seconds, or with alcohol in order to remove the transient microbiota (World Health Organization, 2009).

However, the prolonged hospitalization negatively affects the oral health of patients, with oral candidiasis and pneumonia as the main repercussions (Rodrigues, et al., 2017). It can affect the quality of life of patients, prolong their stay in the hospital and increase medical costs (Prendergast, et al., 2013).

In this context, periodontitis in patients with systemic involvement may increase the risk of atherosclerosis, myocardial 
infarction, diabetes complications (Steffens \&, 2018; Pascoaloti, et al., 2019). In diabetes, there are biochemical changes, the production of AGEs (advanced glycation), intracellular hyperglycemia, changes in saliva, immunological disorders, increased production of cytokines and inflammatory mediators that increase the chances of developing periodontal disease (ALVES, et al., 2007).

Periodontitis is a risk factor for cardiovascular diseases due to asymptomatic transient bacteremia caused by the accumulation of bacterial plaque from the periodontium and migrates to the bloodstream, which can induce infiltration of inflammatory cells in the great arteries and proliferation of vascular smooth muscle, constituting aspects of teratogenesis (Paizan $\&, 2009)$.

With this, to compose the longitudinality of care in a multi-professional team (Brazil, 2018), hospital dentistry addresses critical patients, aiming at the prevention of complications through the elimination of infection areas, treatment of oral changes, educational actions for family members, and technical staff (Miranda, 2018; Blum, et al., 2017).

Thus, this article aims to assess oral health before and after dental care to adult patients restricted to bed with trauma sequelae, admitted to the tertiary hospital Instituto Doutor José Frota (IJF), located in the city of Fortaleza, in the state from Ceará, Brazil.

\section{Methodology}

\subsection{Type of study}

This is a longitudinal and interventional study with a quantitative approach that covers the impact of oral health after two sessions of bedside dental care for patients admitted to the IJF-CE.

\subsection{Patients and study design}

The IJF is a health care hospital in the city of Fortaleza/CE that is a regional reference in helping victims of highly complex traumas, burns, and intoxications.

This research included adult patients restricted to bed, with locomotor deficiency, cognitive deficiency, unresponsive, diagnosed with TBI, ST, exogenous intoxications (drug substances) and whose responsible companion signed the Informed Consent Form (ICF). Therefore, we excluded patients who walk who do not enable care and were discharged without a companion.

Data collection was carried out from January to December 2020, by sampling for convenience by the dentist at the Residence of the School of Public Health of the State of Ceará (ESP-CE-Residência da Escola de Saúde Pública do Estado do Ceará).

The collection instruments were: a) Clinical Record with the following variables: age, date of birth, gender, marital status, comorbidity (s), diagnosis of hospitalization, medications (medication classes), palliative care, respiratory system, diet, number of days and initial date of hospitalization in the ICU, in the research patient unit; and b) Dental record containing the odontogram, type of dental prosthesis, index of decayed, missing and filled teeth (DMFT), the Barrow Oral Care Protocol index (BOCP) and the Bedside oral exam index (BOE) by Prendergast, et al., (2013), additional information, need for treatment, treatment plan, and clinical evolution.

To quantify the number of decayed, missing, and filled teeth to obtain the degree of prevalence of dental caries, the DMFT was used and classified as very low (0.0 to 1.1), low (1.2 to 2.6), moderate (2.7 to 4.4), high (4.5 to 6.5) and very high (6.6 and more) - considering that increasing values are proportional to poorer oral health (Oliveira, et al., 1998; Agnelli, 2015). Third molars were not included in the count. 
We used the BOE index to examine swallowing, lips, tongue, saliva, mucous membranes, gums, teeth, dentures, and odors by oral and perioral inspection and measure the results in 1 for normal dysfunction, 2 for moderate dysfunction, and 3 for severe dysfunction - having the sum between 8 (excellent oral health) to 24 (oral health problems). The lower the score, the healthier the mouth.

To categorize the BOE result, the values of 8-10 were distinguished as good oral hygiene, 10-14 as poor oral hygiene, and 25-24 as deteriorated oral hygiene according to the BOCP index (Prendergast, et al., 2013).

The evaluation of the type of respiratory system was divided into ambient air, tracheostomy (TQT) in ambient air, TQT with macronebulization, and artificial (by venturi). Also, the diet was classified as oral, parenteral, and enteral, which was subdivided into the nasogastric tube (SNG), nasoenteral tube (SNE), and gastrostomy tube (GTT).

The procedures performed at the bedside were: oral hygiene guidance for the responsible companion (, temporary (restorative glass ionomer cement) and permanent (nanohybrid composite resins) restorations, topical application of fluoride, supra, and infra gingival scraping, low-level laser therapy, extractions, lip hydration, removal of dental plaque and pseudomembranes in the oral mucosa.

The brushing technique performed and guided by the caregiver was the modified stillman technique using mouthwash $-0.12 \%$ chlorhexidine - without alcohol as a chemical agent for oral hygiene. The evaluator dentist proposed to the caregiver to sanitize the back of the tongue with a tongue scraper or wooden tongue depressor wrapped with sterile gauze, this being alternated with dry gauze and another with gauze moistened with $0.12 \%$ chlorhexidine and used by the evaluator.

The initial evaluation was carried out with the applicability of the clinical record and the dental record. Subsequently, two dental appointments were made for clinical procedures. Seven days after the last dental clinic intervention, the DMFT and BOE indices were applied to monitor patients' oral health.

\subsection{Analysis of results and statistics}

We collected the results, putting the clinical record and the dental record in Microsoft Word Professional Plus 2019. The data were transcribed to Microsoft Excel Professional Plus 2019 spreadsheets, in tables and graphs. We analyzed mean minimum, maximum, standard deviation, and percentages.

For statistical analyzes, data were used that were expressed as absolute and percentage frequencies and associated with the total length of stay, in the ICU and the research unit, using Fisher's exact test and Pearson's chi-square test using the Statistical Package for the Social Sciences software (SPSS) 2019 with 95\% confidence.

The study was approved by the Ethics Committee of the Instituto Doutor José Frota - IJF/Fortaleza City Hall, Ceará, with CAAE number 25886019.8.0000.5047, respecting Resolution 466/2012 of the National Health Council (CNS) ${ }^{13}$.

\section{Results and Discussion}

\subsection{Demographic and clinical data}

The study population was 39 patients with the most prevalent age group between 28-37 years old [10 (26\%)]; mean age of 45 years old [standard deviation (DV) 17.18], ranging from 19 to 78 years old; there was a prevalence of males [35 (89.74\%)], mean days of hospital stay was 74.5 days and in the unit of 45 days; mostly female patients had the number of days of hospitalization up to 60 days $(\mathrm{p}=0.010)$ (Table 1$)$. 
Table 1 - Association of the number of days of hospitalization with the epidemiological profile of the hospital. Fortaleza-CE.

\begin{tabular}{|c|c|c|c|c|c|c|c|c|c|c|}
\hline & \multicolumn{3}{|c|}{ Hospitalization days } & \multicolumn{3}{|c|}{ ICU } & \multicolumn{4}{|c|}{ IURP } \\
\hline & \multirow[b]{2}{*}{ Total } & \multicolumn{2}{|l|}{ Until 60} & \multicolumn{3}{|c|}{ Until } & \multicolumn{3}{|c|}{ Until } & \multirow{2}{*}{$\begin{array}{c}\text { p- } \\
\text { Value }\end{array}$} \\
\hline & & days & $>60$ day & p-Valor & 20 & $>20$ & p-Value & 30 & $>\mathbf{3 0}$ & \\
\hline All the sample & 39 & $18(46.2 \%)$ & $21(53.8 \%)$ & - & $14(45.2 \%)$ & $17(54.8 \%)$ & - & $19(48.7 \%)$ & $\begin{array}{c}20 \\
(51.3 \%)\end{array}$ & ) \\
\hline \multicolumn{11}{|l|}{ Sex } \\
\hline \multirow{3}{*}{$\begin{array}{l}\text { Feminine } \\
\text { Masculine }\end{array}$} & $5(12.8 \%)$ & $5(27.8 \%)^{*}$ & $0(0.0 \%)$ & 0,010 & $3(21.4 \%)$ & $1(5.9 \%)$ & 0,199 & $4(21.1 \%)$ & $1(5.0 \%)$ & 0,134 \\
\hline & & & 21 & & & & & & 19 & \\
\hline & $34(87.2 \%)$ & $13(72.2 \%)$ & $(100.0 \%)^{*}$ & & $11(78.6 \%)$ & $16(94.1 \%)$ & & $15(78.9 \%)$ & $(95.0 \%)$ & \\
\hline \multicolumn{11}{|l|}{ Companion } \\
\hline \multirow[t]{2}{*}{ Parents } & & & & 0,735 & & & 0,578 & & 2 & 0,270 \\
\hline & $4(10.3 \%)$ & $2(11.1 \%)$ & $2(9.5 \%)$ & & $2(14.3 \%)$ & $2(11.8 \%)$ & & $2(10.5 \%)$ & $(10.0 \%)$ & \\
\hline \multirow[t]{2}{*}{ Spouse } & & & & & & & & & 4 & \\
\hline & $6(15.4 \%)$ & $2(11.1 \%)$ & $4(19.0 \%)$ & & $3(21.4 \%)$ & $1(5.9 \%)$ & & $2(10.5 \%)$ & $(20.0 \%)$ & \\
\hline \multicolumn{11}{|l|}{ Another family } \\
\hline \multirow[t]{2}{*}{ Son/daughter } & & & & & & & & & 4 & \\
\hline & $8(20.5 \%)$ & $3(16.7 \%)$ & $5(23.8 \%)$ & & $2(14.3 \%)$ & $4(.5 \%)$ & & $4(21.1 \%)$ & $(20.0 \%)$ & \\
\hline \multirow[t]{2}{*}{ Others } & & & & & & & & & 10 & \\
\hline & $17(43.6 \%)$ & $8(44.4 \%)$ & $9(42.9 \%)$ & & $5(35.7 \%)$ & $9(52.9 \%)$ & & $7(36.8 \%)$ & $(50.0 \%)$ & \\
\hline \multicolumn{11}{|l|}{ Married } \\
\hline \multirow[t]{2}{*}{ No } & & & & 0,284 & & & 0,791 & & 13 & 0,557 \\
\hline & $27(69.2 \%)$ & $14(77.8 \%)$ & $13(61.9 \%)$ & & $11(78.6 \%)$ & $14(82.4 \%)$ & & $14(73.7 \%)$ & $(65.0 \%)$ & \\
\hline \multirow[t]{2}{*}{ yes } & & & & & & & & & 7 & \\
\hline & $12(30.8 \%)$ & $4(22.2 \%)$ & $8(38.1 \%)$ & & $3(21.4 \%)$ & $3(17.6 \%)$ & & $5(26.3 \%)$ & $(35.0 \%)$ & \\
\hline \multicolumn{11}{|l|}{ Diagnóstico } \\
\hline TBI with conservative & & & & 0,505 & & & 0,528 & & 10 & 0,158 \\
\hline treatment & $18(46.2 \%)$ & $8(44.4 \%)$ & $10(47.6 \%)$ & & $6(42.9 \%)$ & $7(41.2 \%)$ & & $8(42.1 \%)$ & $(50.0 \%)$ & \\
\hline TBI with surgical & & & & & & & & & 8 & \\
\hline treatment & $16(41.0 \%)$ & $8(44.4 \%)$ & $8(38.1 \%)$ & & $6(42.9 \%)$ & $7(41.2 \%)$ & & $8(42.1 \%)$ & $(40.0 \%)$ & \\
\hline TBI with conservative & & & & & & & & & 2 & \\
\hline treatment and ST & $2(5.1 \%)$ & $0(0.0 \%)$ & $2(9.5 \%)$ & & $0(0.0 \%)$ & $2(11.8 \%)$ & & $0(0.0 \%)$ & $(10.0 \%)$ & \\
\hline Into exogenous & $3(7.7 \%)$ & $2(11.1 \%)$ & $1(4.8 \%)$ & & $2(14.3 \%)$ & $1(5.9 \%)$ & & $3(15.8 \%)$ & $0(0.0 \%)$ & \\
\hline
\end{tabular}

Note: Research patients were divided by number of days of hospitalization, in the ICU and in the research patients' inpatient unit and categorized into 60 days, 20 days and 30 days, respectively. The variables sex, companion, married and diagnosis were associated with the number of days of hospitalization. Acronyms: intensive care unit (ICU), inpatient unit for research patients (IURP), spinal trauma (ST),traumatic brain injury (TBI) and exogenous intoxication (into exogenous). $* \mathrm{p}<0.05$, Fisher's exact test or Pearson's chi-square test (n, \%). Source: Authors.

In the systemic conditions of the study population, there was a predominance of $24(61.54 \%)$ without comorbidities, but 07 (17.95\%) diabetes mellitus and 07 (17.95\%) systemic arterial hypertension were the most prevalent systemic conditions.

The most prevalent clinical data we found was $23(59 \%)$ patients were not in palliative care; $36(92.31 \%)$ had a diagnosis of TBI, with conservative TBI being the most prevalent [18 (46.15\%)]; 31 (79\%) had an enteral diet, with SNE being the most present [12 (31\%)]; $23(59 \%)$ had a respiratory system by tracheostomy (TQT), and among these 14 (36\%) used TQT in room air (Graph 1). 
Graph 1 - Age range of the research patients. Fortaleza-CE.

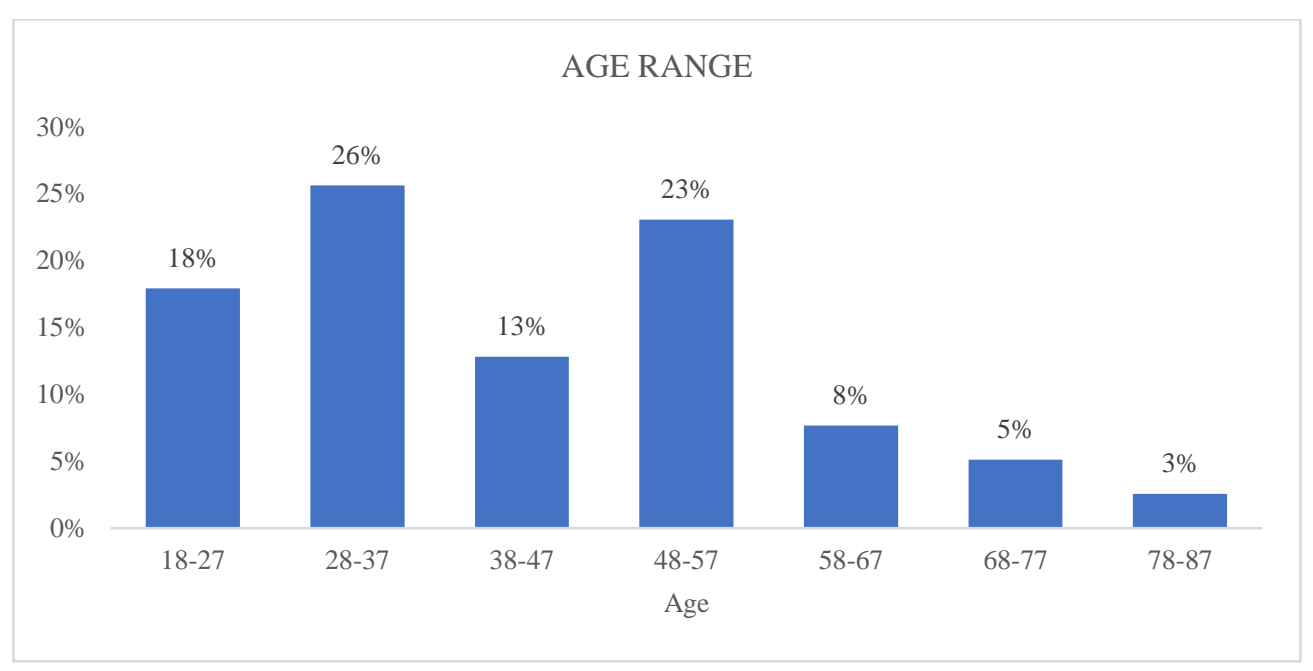

Source: Authors.

The patients used six medications on average, and the most prevalent were: antacids, anticoagulants, antibiotics, and antipsychotics, with the following medications being more prescribed: 29 (96.6\%) omeprazole, 18 (60\%) enoxaparin sodium, $09(50 \%)$ meropenem, $08(44.44 \%)$ quetiapine (Graph 2).

Graph 2 - Medicated classes of hospitalized patients. Fortaleza-CE.

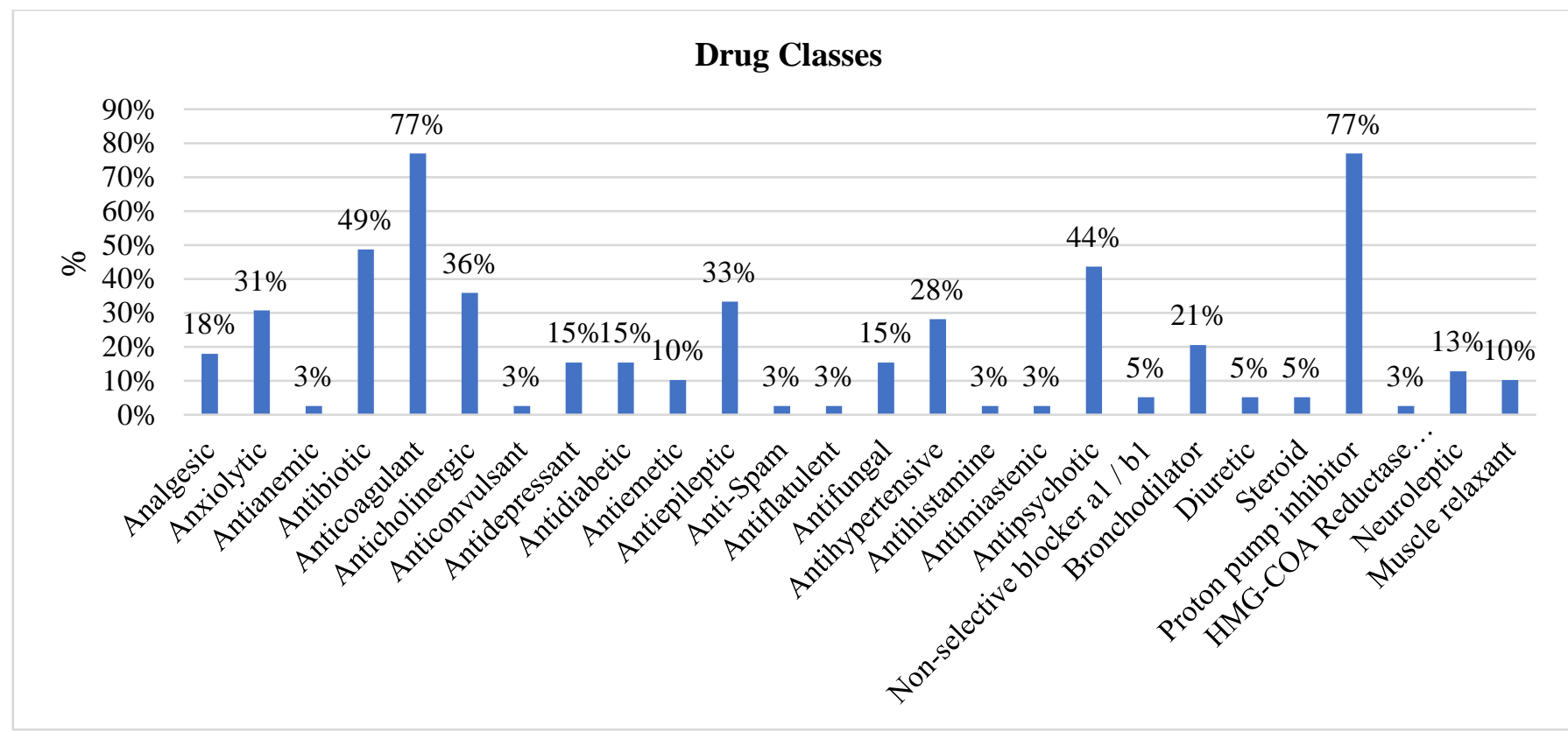

\section{Source: Authors.}

When the form of diet was correlated with the total length of stay, patients on an oral diet had a statistically significant correlation $(\mathrm{p}=0.042)$. In this description, we observed that $5(27.8 \%)$ oral diet and $8(44.4 \%)$ diet by SNE hospitalized up to 60 days were statistically relevant. The results were obtained in numbers of days greater than 60 , in which 7 (33.3\%) GTT and $8(38.1 \%)$ SNG obtained statistical relevance $(\mathrm{p}<0.05)$ (Table 2$)$. 
Table 2 - Association of the number of days of hospitalization with the clinical profile of the hospital. Fortaleza-CE.

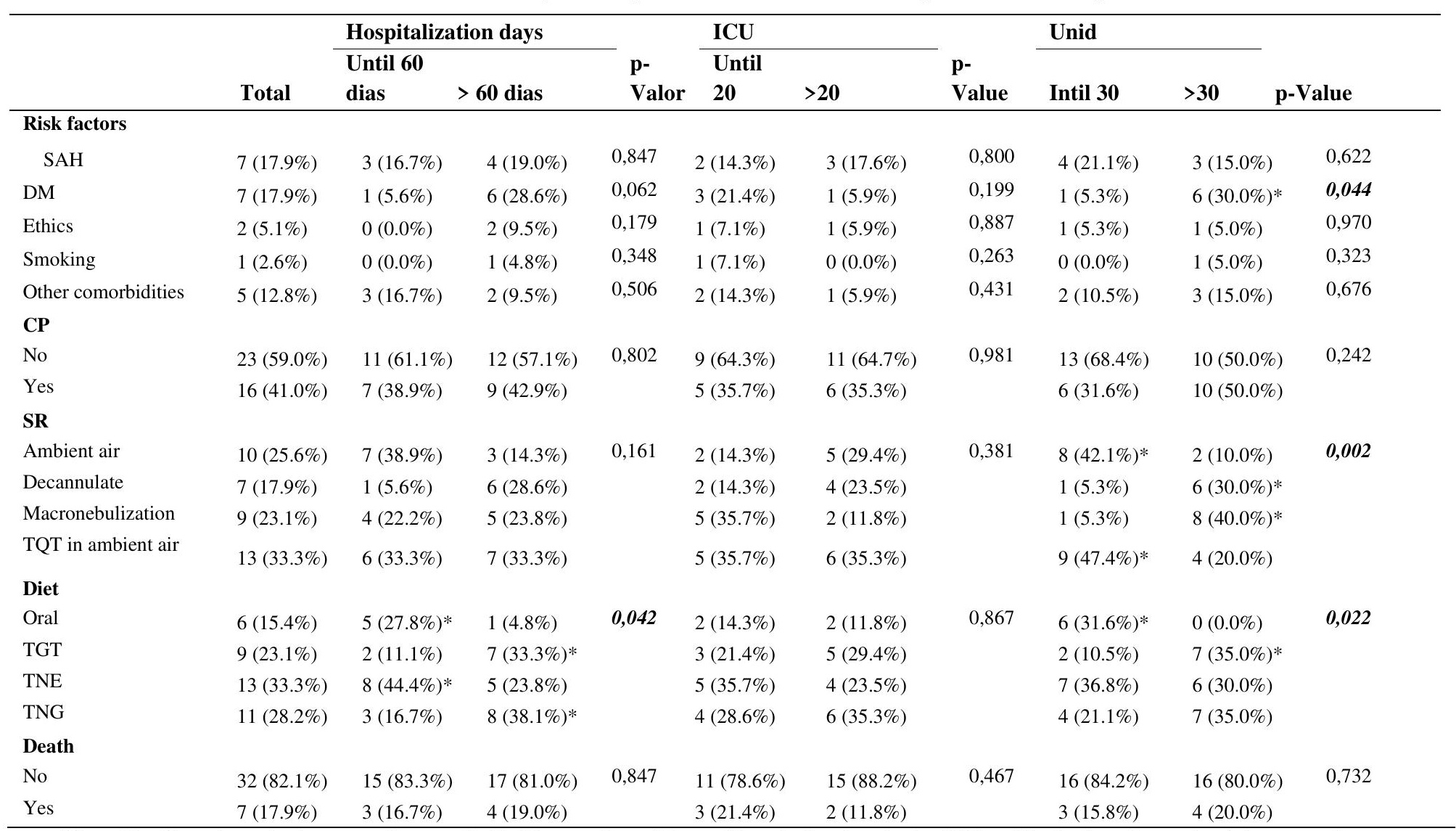

Note: The 39 patients in the research were divided by number of days of hospitalization, in the ICU and in the inpatient unit of the research patients and categorized into 60 days, 20 days and 30 days, respectively. The variables were risk factors, palliative care, respiratory system, diet, death were associated with the number of days of hospitalization. Acronyms: intensive care unit (ICU), inpatient unit for research patients (UNID), systemic arterial hypertension (SAH), diabetes mellitus (DM), palliative care (CP), respiratory system (SR), tracheostomy (TQT), nasoenteral tube (TNE), nasogastric tube (TNG), gastrostomy tube (TGT). * p <0.05, Fisher's exact test or Pearson's chi-square test (n, \%). Source: Authors.

When the form of the diet was correlated with the length of stay in the unit of the patients in this study, patients with an oral diet showed a statistically significant correlation with a p-value of 0.022 . In this description, we observed that 6 (31.6\%) patients with an oral diet hospitalized up to 30 days had statistical relevance. The 7 (35.0\%) patients on the GTT diet who were hospitalized for more than 30 days showed a statistical correlation $(\mathrm{p}<0.05)$ (Table 2$)$.

When correlating the risk factors of hospitalized patients with the length of stay, diabetic patients have a statistically significant correlation $(\mathrm{p}=0.044)$ (Table 2).

The type of respiratory system obtained a statistically significant correlation $(\mathrm{p}=0.002)$ when correlated with the length of stay in the intervention unit of the patients in this research. In this, $8(42.1 \%)$ patients were in room air and $9(47.4 \%)$ patients with TQT in room air were hospitalized for up to 30 days, while $6(30.0 \%)$ patients with decannulation and $8(40.0 \%)$ patients with macronebulization were hospitalized for a period more than 30 days (Table 2).

\subsection{Oral health profile}

In the initial oral examination, there was a prevalence of missing and decayed teeth, an average BOE index of 14.12 (DV 2.4), and a DMFT of 12.9. The 29-38 age group had more decayed and filled teeth, while the 48-58 age group had more missing teeth and a high BOE index. The most prevalent dental needs were oral hygiene instruction, oral hygiene, supragingival scraping, and restoration (Graph 3). 
Graph 3 - Dental needs of users with trauma sequelae. Fortaleza-CE.

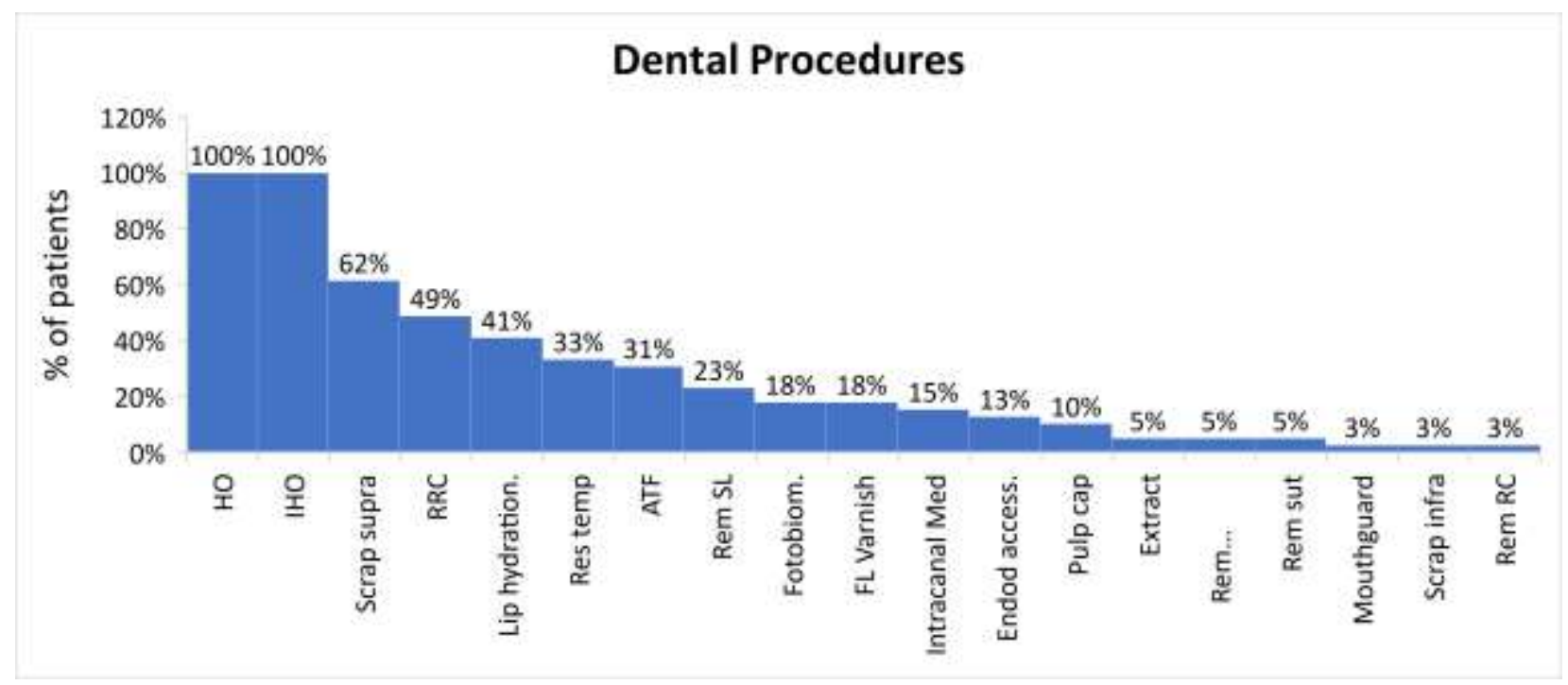

Acronyms: HO- Oral Hygiene, IHO: Oral Hygiene Instruction, Scrap Supra: Supragingival scraping, RRC: Composite resin restoration, Lip hydr: Lip hydration, Res temp: Temporary restoration, ATF: topical application of fluorine, Rem SL: Removal Lingual Saburra, Fotobiom: photobiomodulation (laser), FL: fluorine, Med: medication, Endod access.: endodontic (channel), Pulp Cap: pulp capping, Extract: tooth extraction, Rem pseudomem: pseudomembrane removal, Sut rem: suture removal, Scrap infra : infragingival scraping, Rem RC: removal of composite resin. Source: Authors.

According to the previous evaluation using the BOE, there were 31 cases (79\%) of the tongue with lingual coating, 27 (69\%) of dry lips, 24 (52\%) of inability to swallow, 23 (59\%) of mucous membranes with biofilm and 22 (56\%) of general debris on the dental surfaces. They were the alterations of the total of twenty and on average 5.38 (DV 2.00) per patient that most increased the index value.

In the evaluation after dental care using the BOE, 11 (28\%) had dry lips, 18 (43\%) were unable to swallow and 05 $(13 \%)$ had local debris on the dental surfaces. They were the prevalent changes that most increased the value of the tooth index, corresponding to an average of 1.28 (DV 1.33) of change per patient (Table 3). 
Table 3 - Oral health profile after dental intervention. Fortaleza-CE.

\begin{tabular}{|c|c|c|c|c|c|c|}
\hline & Normal & & Moderate & & Severe & \\
\hline & Previous & After & Previous & After & Previous & After \\
\hline Act of swallowing & $10(26 \%)$ & $17(44 \%)$ & $06(15 \%)$ & $03(8 \%)$ & $23(59 \%)$ & $19(49 \%)$ \\
\hline Lips & $09(23 \%)$ & $27(69 \%)$ & $26(67 \%)$ & $12(31 \%)$ & $04(10 \%)$ & $0(0 \%)$ \\
\hline Tongue & $04(10 \%)$ & $36(92 \%)$ & $34(87 \%)$ & $03(8 \%)$ & $01(3 \%)$ & $0(0 \%)$ \\
\hline Spittle & $30(77 \%)$ & $34(87 \%)$ & $7(18 \%)$ & $03(8 \%)$ & $02(5 \%)$ & $2(5 \%)$ \\
\hline Mucous Membrane & $13(33 \%)$ & $35(90 \%)$ & $26(67 \%)$ & $03(8 \%)$ & $0(0 \%)$ & $02(5 \%)$ \\
\hline Gum & $19(49 \%)$ & $35(90 \%)$ & $18(46 \%)$ & $04(10 \%)$ & $02(5 \%)$ & $00(0 \%)$ \\
\hline Teeth & $07(18 \%)$ & $32(82 \%)$ & $12(31 \%)$ & $06(15 \%)$ & $20(51 \%)$ & $01(3 \%)$ \\
\hline Odor & $35(90 \%)$ & $38(97 \%)$ & $01(3 \%)$ & $01(3 \%)$ & $03(8 \%)$ & $00(0 \%)$ \\
\hline \multicolumn{7}{|l|}{ BOE Result } \\
\hline $\begin{array}{l}\text { Good oral health } \\
(8-10)\end{array}$ & $04(10 \%)$ & $26(67 \%)$ & & & & \\
\hline $\begin{array}{l}\text { Poor oral health } \\
(11-14)\end{array}$ & $17(44 \%)$ & $13(33 \%)$ & & & & \\
\hline $\begin{array}{l}\text { Deteriorated oral health } \\
(15-24)\end{array}$ & $18(46 \%)$ & $00(0 \%)$ & & & & \\
\hline
\end{tabular}

Note: Comparison of the Bedside oral exam (BOE) Index by Prendergast et al. (2013), translated as Oral Head Examination prior to and after dental interventions. Source: Authors.

After bedside dental care, there was a $46 \%$ reduction in the number of decayed teeth and an increase of $53 \%$ in the number of filled teeth. Also, the final BOE reduced $4.18(29.60 \%)$ from the initial value, reflecting an improvement in oral health (Graph 4).

Graph 4 - Quantitative of decayed, filled and lost dental elements per person before and after dental care. Fortaleza-CE.

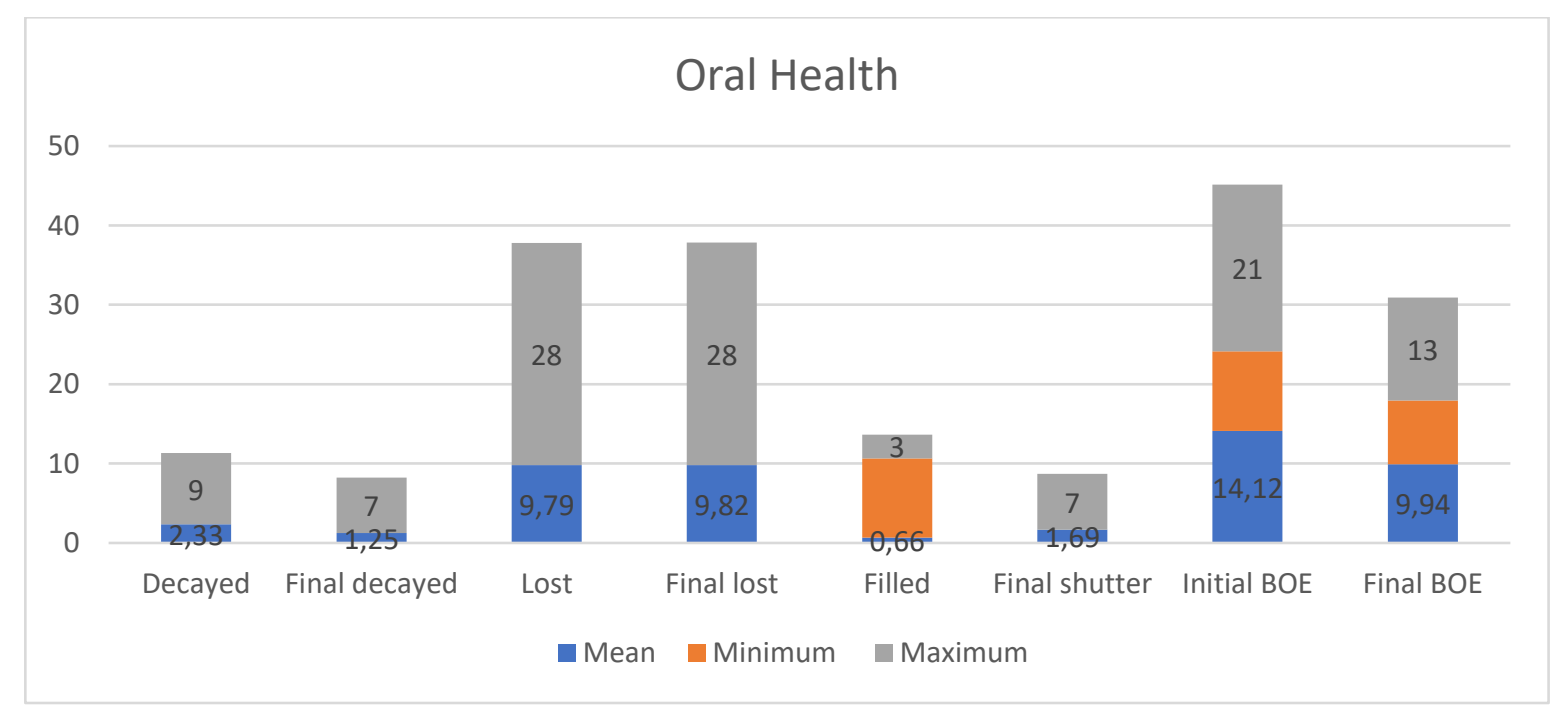

Source: Authors. 
In the initial evaluation with BOE index, the variables with the highest values categorized as severe dysfunction were the act of swallowing [23 (59\%)] and teeth [20 (51\%)]; as moderate dysfunction were lips [20 (51\%)], tongue [34 (87\%)] and mucous membrane [26 (67\%)]; as normal were saliva [30 (77\%)], gum [19 (49\%] and odor [35 (90\%)] (Table 1).

In the final evaluation with BOE index, only the variable act of swallowing [19 (49\%)] was categorized as severe dysfunction; and the lips [27 (69\%)], tongue [36 (92\%)], saliva [34 (87\%)], mucous membranes [35 (90\%)], gum [35 (90\%)], teeth [32 (82\%)], odor [38 (97\%)] were normal (Table 1).

However, the dental approach had a satisfactory impact on the patient's oral health and was confirmed by the BOE result, in which the variable of good oral health increased by $57 \%$, the variable of poor oral health decreased by $11 \%$, and deteriorated oral health reduced to $0 \%$ (Table 1 ).

The BOE helps to monitor the oral health of patients in tertiary care (Aktan \& Eser, 2017). For Prendergast, et al., 2013, the BOE provided a narrative and visual reference to the health team for oral health assessments (Prendergast, et al., 2013). In this study, the BOE index was an easy tool to perform, corroborating with Prendergast, 2012.

Patients with neurological sequelae, as with a diagnosis of TBI, may be dependent on the practice of self-care with general and oral health due to physical, cognitive, behavioral deficiencies and, consequently, difficulties in cleaning the oral cavity (Spezzia, 2019). In the research participants, there was a preponderance of patients with TBI, reflecting the need for centralized care.

As the number of missing teeth is associated with severe cognitive impairment (Luo, et al., 2015), patients with trauma sequelae in this study should be monitored to enable the prevention and early diagnosis of oral changes.

Caregivers commonly have limitations in the patient's oral hygiene due to the degree of cognitive and/or locomotor impairment caused by the patient's underlying disease, enabling the emergence of conditioning factors for caries and periodontal disease (Spezzia, 2019) (Graph 3).

The accumulation of plaque and dental calculus by inappropriate brushing techniques can increase the risk two to five times of the patient having periodontitis (Lertpimonchai, et al., 2017). This effect is stronger than the association of the presence of periodontitis with diabetes mellitus, smoking, or obesity. In contrast, regular brushing can reduce periodontitis by $34 \%$ (Lertpimonchai, et al., 2017). With that, dental interventions helped in the recovery of the oral health of the research patients.

The absence of oral hygiene increases the quantity and complexity of dental plaque, capable of originating gramnegative pathogens after 72 hours, such as Staphylococcus aureus and Pseudomonas aeruginosa, which can progress to infections in the oral cavity or to systemic contamination, and may impair the cough reflex and increase secretion (Yurdanur \& Yagmur, 2016).

The main risk factors for nosocomial pneumonia are age over 70 years old, depression in the level of consciousness, lung diseases, use of nasogastric tubes, tracheostomy, severe trauma, bronchoaspiration, antacids, orotracheal intubation, length of hospital stay, multiple comorbidities (Mitchell, et al., 2019). Of these, dysphagia (79\% enteral nutrition), tracheostomy (59\%), poor oral hygiene (100\%), 74 days of average hospital stay, and use of antacids (77\%) are present in the study (Graph 2 and Graph 3).

The preventive strategy most used to reduce nosocomial pneumonia was oral hygiene (Mitchell, et al, 2019; Manger, et al., 2017). Among the highest quality studies that evaluated the impact of improvements in oral hygiene, there was the presence of dental professionals. However, few studies have presented the dentist in the hospital environment (Manger, et al., 2017).

Also, the average number of medications was six per patient, which may be more predisposed to changes in the oral mucosa, such as erythema multiforme (greater number of medications), persistent oral dryness (tricyclic antidepressants, benzodiazepines, and beta-blockers), oral lichen planus ( $\beta$-blockers and sulfonylureas), candidiasis (oral dryness from drugs) 
(Porter, et al., 2017). Although not many lesions were observed in the oral cavity in the study and considering that the average number of drug classes is high, we need to evaluate and monitor the appearance of lesions of the oral, perioral, and saliva mucosa.

Celik \& Easer (2017) concluded that the main risk factors for worsening oral health in ICU patients assessed with BOE index were unconscious patients, old age, unable to oral diet, reduced oral care, the greater number of medications, absence of a protocol of oral care (Celik, et al., 2017). As much as this research was not carried out in the ICU, 76\% of the patients come from it, in addition to being commonly non-communicative, with enteral diet, use of various medications, and accompanied by caregivers who do not intervene adequately in patients' oral hygiene.

Although oral exams in bedside patients are difficult due to lighting conditions, the non-ergonomic environment, and the professional position (Quintanilha, et al., 2020), continuous monitoring of the oral mucosa and dental surfaces is necessary since improvements in people's oral health can generate gains in well-being (Matsuyama, et al., 2019). Although this study was carried out with patients in the hospital regime who are not admitted to the ICU and the improvement of oral health was noticeable after dental interventions in the bed, we consider that this study has limitations because of the small size of the sample, the absence of the control population, the heterogeneity of the population and the patient's short-term follow-up.

\section{Conclusion}

Dental care performed on the bed of patients with trauma sequelae proved to be effective in reducing the number of decayed teeth and increasing the number of filled teeth, also improving the health of the gingival mucosa, and reducing the likelihood of associated oral manifestations of systemic disease, periodontal disease, and nosocomial pneumonia. However, we need to use an oral health continuity assessment tool to monitor and prevent sequelae in the oral and perioral structures of the patient restricted to the bed.

\section{Acknowledgments}

To all the employees of the research hospital for their support and for providing an environment conducive to the development of this scientific article.

\section{References}

Agnelli, P. B. (2015). Variation of the CPOD index in Brazil from 1980 to 2010. Rev. Bras. Odontol, 72 (1), 10-15.

Aktan, G. G, \& Eser, I. (2017). Examination of intensive care unit patients' oral health. International Journal of Nursing Practice, $23(6), 1-9.10 .1111$ / ijn.12592.

Alves, C.; Andion J.; Brandão, M.; \& Menezes, R (2007). Mecanismos patogênicos da doença periodontal associada ao diabetes mellitus. Arquivos Brasileiros de Endocrinologia \& Metabologia, 51, 1050-1057, 2007. dx.doi.org/10.1590/S0004-27302007000700005.

Blum, D. F. C., Munaretto, J., Baeder, F. M., Gomez, J., Castro, C. P. P., \& Bona, A. D. (2017). Influence of the presence of professionals in dentistry and protocols for oral health care in the nursing team of the intensive care unit. Survey study. Rev. Bras. Ter. Intensive, 29 (3), $391-393$.

Brazil (2009). National Health Surveillance Agency. Patient Safety in Health Services: Hand Hygiene / National Health Surveillance Agency. Brasília: Anvisa.

Brazil (2011). Ministry of Health. Health Surveillance Secretariat. Health Situation Analysis Department. Saúde Brasil 2010: A Health Situation Analysis of selected evidence of the impact of health surveillance actions. Brasília / DF.

Brazil (2013). Ministry of Health. Office of the Minister.

Brazil (2018). Ministry of Health. Department of Health Care. Department of Primary Care. Oral health in the Unified Health System [electronic resource] / Ministry of Health, Department of Health Care, Department of Primary Care. Ministry of Health.

Celik, G. G., \& Eser I. (2017). Examination of intensive care unit patients' oral health. Int J Nurs Pract. Dec;23(6): 1-19. 10.1111/ijn.12592.

Carvalho, I. C. C. M., \& Saraiva, I. S (2015). Perfil das vítimas de trauma atendidas pelo serviço de atendimento móvel de urgência. $R$. Interd., 8(1):137-148.

Fernando, S. A., Gray, T. J., \& Gottlieb, T. (2017). Healthcare-acquired infections: prevention strategies. Internal Medicine Journal, 17(12):1341-1351, https://doi.org/10.1111/imj.13642. 
Government of the State of Espírito Santo (2018). Emergency Care for Trauma Victims - Clinical Guidelines. State Health Secretariat of Espírito Santo, 1-62.

Khan, H. A., Baig, F. K., \& Mehboob R. (2015). Nosocomial infections and their control strategies. Asian Pac J Trop Biomed, 5(7): 509-514. https://doi.org/10.1016/j.apjtb.2015.05.001.

Khan, H. A., Baig, F. K., \& Mehboob R. (2017). Nosocomial infections: Epidemiology, prevention, control and surveillance. Pac J Trop Biomed.,7(5): 478482. https://doi.org/10.1016/j.apjtb.2017.01.019.

Lertpimonchai, A., Rattanasiri, S., Vallibhakara, A. S., Attia, J., \& Thakkinstian, A. (2017). The association between oral hygiene and periodontitis: a systematic review and meta-analysis. Int Dent J., 67(6), 332-343. 10.1111/idj.12317.

Luo, J., Wu, B., Zhao, Q., Guo, Q., Meng, H., Yu, L. et al (2015). Association between Tooth Loss and Cognitive Function among 3063 Chinese Older Adults: A Community-Based Study. PLoS One, 10(3), 1-11. 10.1371/journal.pone.0120986.

Manger, D., Walshaw, M., Fitzgerald, R., Doughty, J., Wanyonyi, K. L., White, S. et al (2017). Evidence summary: the relationship between oral health and pulmonary disease. Br Dent J., 222(7), 527-533. 10.1038/sj.bdj.2017.315.

Matsuyama, Y., Tsakos, G., Listl, S., Aida, J., \& Watt, R.G. (2019). Impact of Dental Diseases on Quality-Adjusted Life Expectancy in US Adults. J Dent Res., 98(5), 510-516. 10.1177/0022034519833353.

Miranda, A. F. (2018). Hospital Dentistry: Inpatient Units, Surgical Center and Intensive Care Unit. Science \& Dentistry Magazine, 2 (2), 1-5.

Mitchell, B. G., Russo, P. L., Cheng, A. C., Stewardson, A. J. S., Rosebrock, H., Curtish, S. J. et al (2019). Strategies to reduce non-ventilator-associated hospitalacquired pneumonia: A systematic review. Infect Dis Health, 24(4), 229-239. 10.1016/j.idh.2019.06.002.

Oliveira, A. G. R. C., Unfer, B., Costa, I. C. C., Arcieri, R. M., Guimarães, L. O. O., \& Saliba, N. A. (1998). Epidemiological surveys on oral health: analysis of the methodology proposed by the World Health Organization. Rev. Bras. Epidemiol. 1 (2), 177-189.

Paizan, M. L, \& Martin, J. F. V. (2009). Associação entre doença periodontal, doença cardiovascular e hipertensão arterial. Rev Bras Hipertens. 16(3):183-185.

Pascoaloti, M. I. M., Moreira, G. E., Rosa, C. F., Fernandes, L. A., \& Lima, D. C. (2019). Hospital Dentistry: challenges, importance, integration and humanization of treatment. Rev. Ciênc. Ext., 15 (1): 20-35.

Porter, S. R., Mercadante, V., \& Fedele, S. (2017). Oral manifestations of systemic disease. British dental journal, 223(9): 683-691. 10.1038 / sj.bdj.2017.884.

Prendergast,V. (2012). Effects of a standard versus comprehensive oral care protocol among intubated neuroscience ICU patients: Results of a randomized controlled trial. Journal of Neuroscience Nursing, 44(3), 134-146.

Prendergast, V., Kleimanb, C., \& Kinga, M. (2013). The Bedside Oral Exam and the Barrow Oral Care Protocol: translating evidence-based oral care into practice. Intensive Crit Care Nurs, 29(5), 282-90.

Quintanilha, R. M. C., Pereira, M. R. R., Oliveira, S. P, Ragon C. S. T, Agostini M., Júnior A. S et al (2020). Oral health status of patients in intensive care unit: a cross-sectional study. Revista Científica do CRO-RJ (Rio de Janeiro Dental Journal), 4(3), 25-31. https://doi.org/10.29327/24816.4.3-5.

Rodrigues, A. L. S., Malachias, R.C., \& Pacheco C. M. D. (2017). The importance of oral health in hospitalized patients: a review. Rev. Odontol. Univ. Cid., 29 (3), 243-248.

Spezzia, S. (2019). Desordens neurológicas, autocuidado e doenças periodontais. Braz J Periodontol, 29(2):15-21.

Steffens, J. P., \& Marcantonio, R. A. C. (2018). Classification of Periodontal and Peri - implant Diseases and Conditions 2018: Practical guide and Key Points. Dentistry journal of UNESP / Universidade Estadual Paulista (UNESP), 47 (4): 189-197. 10.1590 / 1807-2577.04704.

Wachtel T. L (1985). Epidemiology, classification, initial care, and administrative considerations for critically burned patients. Crit Care Clin,1(1):3-26.

World health organization (2009). WHO Guidelines on Hand Hygiene in Health Care. WHO Library Cataloguing.

Yurdanur, D., \& Yagmur, F. A (2016). Recent View and Evidence-Based Approach to Oral Care of Intensive Care Patient. International Journal of Caring Sciences, 9(2):1177-1185. 